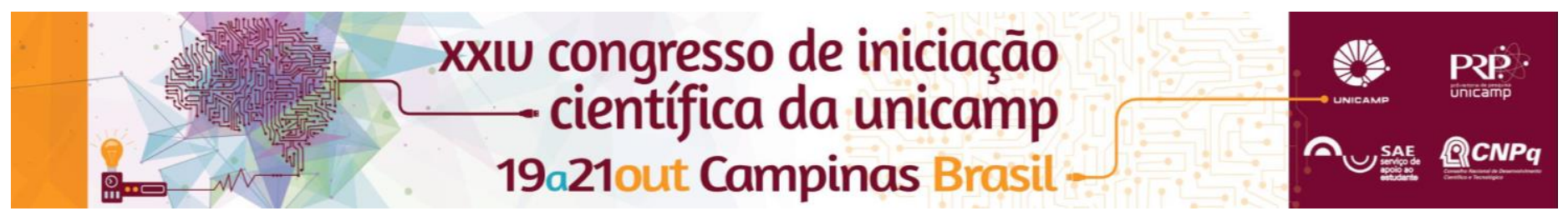

\title{
Estudo dos impactos do adensamento populacional urbano sobre a infraestrutura de saneamento
}

\section{Bruno ladocicco*, Sidney Piochi Bernardini}

\section{Resumo}

O trabalho tem como objetivo principal analisar os impactos na infraestrutura de abastecimento de água, resultantes de diferentes adensamentos urbanos populacionais, através de um estudo de caso no Distrito de Souzas, Campinas, São Paulo. A metodologia consistiu em projetar o sistema de abastecimento de água em um setor urbano na região e, com auxílio do software WaterGEMS, simular adensamentos populacionais diferentes da prevista no planejamento da infraestrutura. Em seguida, mensurou-se seus respectivos impactos na infraestrutura e os correlacionou com os parâmetros urbanísticos de uso e ocupação do solo.

Palavras-chave: Impacto, urbanismo, infraestrutura.

\section{Introdução}

O adensamento urbano pode resultar em problemas relativos à infraestrutura em geral, impactando principalmente as classes de menor renda, que recorrem à ocupação de áreas impróprias e de infraestrutura insuficiente. Além disso, o esvaziamento populacional em centros urbanos, por exemplo, também impacta a rede de infraestrutura que passa a ser subaproveitada.

O crescimento desordenado juntamente com o desenvolvimento de projetos deficientes de infraestrutura, evidenciam as injustiças territoriais nos processos de crescimento das cidades, elevando cada vez mais os problemas urbanos decorrentes.

Esse estudo científico decorre da motivação de enfrentamento desta problemática e na adoção de estratégias para reverter as históricas desigualdades socioterritoriais das cidades brasileiras. $\mathrm{E}$ tem por objetivo verificar, mensurar e analisar as implicações que o adensamento populacional e construtivo urbano tem sobre a infraestrutura existente. Visando assim, auxiliar planejadores urbanos em sua função social com a cidade, contribuindo na tomada de decisão quanto aos parâmetros a serem adotados na legislação urbanística.

\section{Resultados e Discussão}

Simulou-se o setor urbano delimitado, com auxilio do software WaterGEMS, para as densidades populacionais: $10,20,40,50,60,150,300,450$ e 600 hab/ha. Considerando que o adensamento se dá de forma uniforme na área ou de forma pontual, totalizando nove simulações em cada caso. $O$ dimensionamento do sistema foi realizado visando o menor custo da rede de distribuição.

Verificou-se que já para a densidade de 50 hab/ha (incremento com cerca de $60 \%$ na população de projeto), em ambas as formas de adensamento, a rede passou a ter um índice de resiliência próximo a zero e a apresentar diversos tubos com pressões negativas. Portanto, a infraestrutura está comprometida, sendo necessário reforçar a rede com novas tubulações.

O estudo de correção da rede foi feito para as densidades mais elevadas de 150, 300, 450 e 600 hab/ha, chegando até $136 \%$ de acréscimo no custo para adaptar a rede. A Figura 1 resume esses resultados.
Figura 1. Impacto nos custos da infraestrutura.

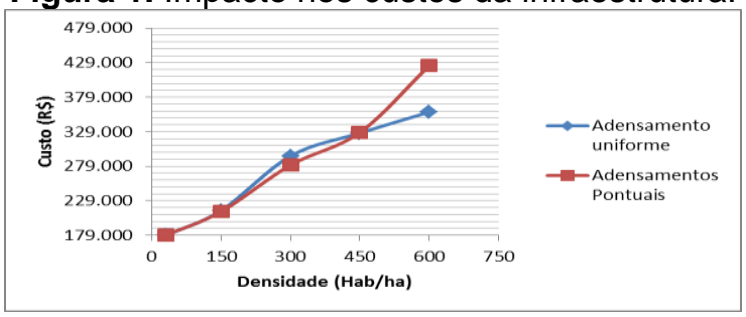

A correlação dentre os impactos nos custos e a cota de terreno por unidade habitacional médio está resumida na Figura 2. Foram considerados, para o cálculo do coeficiente de aproveitamento, tamanhos padrões de loteamento de 50, 100, 150 e $200 \mathrm{~m}^{2}$.

Figura 2. Impactos nos custos por cota de terreno por unidade habitacional, considerando adensamento uniforme.

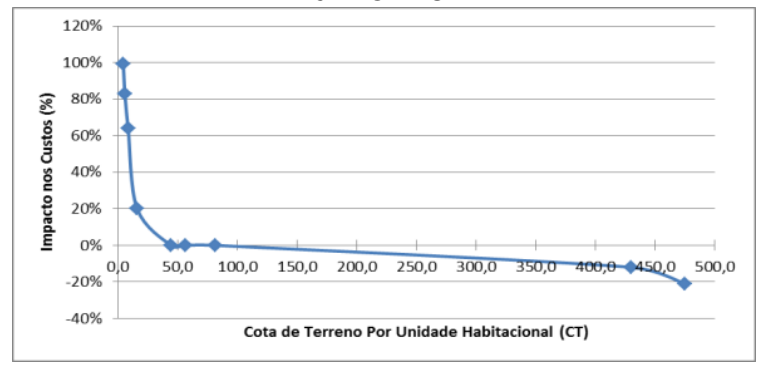

\section{Conclusões}

A infraestrutura de abastecimento de água entrou em colapso após adensamento não muito além do planejado, sendo necessários maiores investimentos na rede. Existem diferenças, entre os tipos de adensamento considerados, dos parâmetros urbanísticos, entretanto os impactos nos custos e na rede devido aos adensamentos se mostraram relativamente próximos.

\section{Agradecimentos}

Agradecemos a Pró-Reitoria de Pesquisa da UNICAMP pela oportunidade a nós oferecida. Ao PIBIC/SAE pelas bolsas concebidas.

\footnotetext{
Tsutiya, M. Tomoyuki; Sobrinho, P. Alem. Coleta e Transporte de Esgoto Sanitário. 2000.

${ }^{2}$ Mascaró, Juan Luís. Desenho Urbano e Custos de Urbanização. 1989.
} 